\title{
STATISTICAL ANALYSIS OF THE EUROPEAN UNION COUNTRIES USING THE METHOD OF STANDARD VARIABLE \\ Dominika Krasňanská ${ }^{1}$, Lubica Hurbánková ${ }^{2}$
}

\begin{abstract}
The aim of this paper is to compare the European Union countries on the basis of selected socio-economic and demographic indicators for the year 2016. The following indicators are selected for analysis: gross domestic product per capita, government gross debt as a percentage of gross domestic product, inflation rate, unemployment rate, total fertility rate, infant mortality rate and crude divorce rate. The contributions of the paper are to order the countries on the basis of the above-mentioned indicators, from the best country to the worst country using one of the multidimensional comparison methods - the method of standard variable. The aim of this method is to replace a number of selected indicators with one final characteristic - an integral indicator. Since the used indicators do not have the same weights, calculations are used on data weighted by weights I (calculated using the coefficient of variation) and weights II (calculated on the basis of the correlation matrix). When evaluating the EU countries on the basis of the selected indicators using the method of standard variable; Luxembourg, Ireland, Denmark and France ranked first. Among the worst countries we include Greece, Hungary, Spain and Portugal.
\end{abstract}

JEL Classification Numbers: C40, E24, J01, J13, DOI: 10.12955/cbup.v7.1359

Keywords: Method of standard variable, European Union countries

\section{Introduction}

In most cases, statistical research focuses on the analysis of only one observed statistical character and its only characteristics in the analyzed file. In many cases, however, it is necessary to examine a statistical file from a lot of aspects and to take into consideration its multiple characteristics displayed by multiple statistical characters (Hair et al., 2010). Statistical files that examine multiple statistical characters at the same time are called multidimensional statistical files. In contrast to one-dimensional statistical files that consider only one statistical character, multidimensional statistical files, apart from analyzing the statistical character separately, also recognize the relationships, links and structures between them (Sharma, 1996). In practice, it is often the case that these processes are often characterized by one or two indicators by solving complicated problems, which significantly distorts their reality. In fact, these processes can be characterized by a set of heterogeneous characters. In these cases, the traditional one-dimensional approach to the solution is very difficult, often not realized. The solution to this problem is devoted to set of statistics and methods, called multidimensional analysis. In this analysis, it is necessary to use multidimensional comparison methods. These methods have recorded rapid growth, especially in recent decades, even though their roots extend to the second half of the $19^{\text {th }}$ century. The most frequent applications of individual methods of multidimensional analysis were performed in the field of psychology, medicine and biology. Among multidimensional comparison methods belong simple multi-criteria comparison methods - the weighted sum order method, the scoring method, the method of standard variable and the method of distance from a fictitious object. The aim of these methods is to replace several selected indicators by which we compare the selected objects - in our case the EU countries, with one final characteristic - an integral indicator, based on which we organize the selected objects.

\section{Literature review}

Stankovičová (2007) focused on the application of multidimensional statistical analysis methods (the principal component analysis and the method of distance from a fictitious object) in the evaluation of EU member states on the basis of the Lisbon Strategy indicators, namely the analysis of employment. Based on the results of multidimensional methods, two countries appear to be the best in this area Sweden and Denmark. The values of their integral indicators are significantly highest. On the other side of the ranking are countries like Malta, Poland, Italy, Hungary, Slovakia, but also Belgium.

Vojtková (2009) in her article evaluates EU member countries on the basis of these areas: differences in unemployment rates, inequality of income distribution, education, a high risk of poverty, especially among the unemployed. She uses a multidimensional evaluation and classification of social cohesion in 27 European Union countries according to hidden dimensions of selected socio-economic indicators for the year 2006.

\footnotetext{
${ }^{1}$ University of Economics in Bratislava, Bratislava, Slovak Republic, d.krasnanskaa@gmail.com

${ }^{2}$ University of Economics in Bratislava, Bratislava, Slovak Republic, lubica.hurbankova@ gmail.com
} 
The comparison of EU countries is also examined by Megyesiová (2010). In her paper she uses multicriteria evaluation methods. She aims to compare countries on the basis of the human development index, which includes three parameters (human health, level of education and material living standard). When evaluation the EU countries on the basis of the human development index, Ireland, the Netherlands, Sweden, France and Luxembourg ranked first. Although the period of implementation of our analysis differs with the Megyesiová analysis period, she also analyses indicators that affect the country's economy, so it is relevant to compare the results. There are the same countries in the location of the countries in our analysis and analysis of Megyesiová, only the order is different.

\section{Data and methodology}

We have selected 28 member countries of the European Union for the analysis. We will make a comparison of the selected countries with the use of 7 socio-economic and demographic indicators for the year 2016. The Eurostat website will serve as a source of the data. We will also briefly define the selected indicators:

Gross domestic product per capita - the ratio of gross domestic product and average population in the year. Gross domestic product is an indicator for a nation's economic situation. It reflects the total value of all goods and services produced less the value of goods and services used for intermediate consumption in their production. Calculations on a per head basis allows for the comparison of economies significantly different in absolute size (Gross domestic product at market prices, 2019).

General gross debt as a percentage of gross domestic product - represents the total general debt as a share of GDP in percent. It is made up of government commitments and is generated by a deficit financing of the state budget (Gola, 2009).

Inflation rate - is defined as the devaluation of the monetary unit, which is manifested by the persistent growth in the price level of products and services in the economy (Šenkýřová, 2010).

Unemployment rate - represents unemployed persons as a percentage of the labor force. The labor force is the total number of people employed and unemployed. The indicator is based on the EU Labor Force Survey (Unemployment, 2019).

Total fertility rate - the mean number of children that would be born alive to a woman during her lifetime if she were to survive and pass through her childbearing years conforming to the fertility rates by age of a given year (Jurčová, 2002).

Infant mortality rate - the ratio of the number of deaths of children under one year of age during the year to the number of live births in that year. The value is expressed per 1000 live births (Mortality, 2019).

Crude divorce rate - is the ratio of the number of divorces during the year to the average population in that year. The value is expressed per 1000 persons (Marriages and divorces, 2019).

In this paper, a multidimensional comparison method is used - the method of standard variable to compare the EU countries on the basis of the above mentioned indicators. The aim of this method is to replace a number of selected indicators, on the basis of which we compare EU countries, with one final characteristic - an integral indicator to order the countries by. By creating an integral indicator, heterogeneous variables, which are expressed in different units and therefore cannot be direct aggregated, are transformed to a homogeneous indicator. Since the used indicators do not have the same weights, calculations are used on the data weighted by weights I (calculated using the coefficient of variation) and weights II (calculated on the basis of the correlation matrix) (more see in Dufek and Minař́ík 1984, Křovák and Študlar 1983).

The principle of the method of standard variable is to transfer values of the indicators to a standard variable. The standard variable is a dimensionless characteristic where the mean value is zero and variance is one (Jílek, 1996).

When applying the method of standard variable, we first calculate the arithmetic means and the standard deviations for the selected indicators. In the next step, we transform the original values of the indicators into a standard shape. In the case of the maximization indicator (the desirable value is the highest value of the indicator), Pažitná and Labudová (2007) calculate the value of the standard variable according to: 


$$
z_{i j}=\frac{x_{i j}-\bar{x}_{j}}{s_{j}}
$$

where: $z_{i j}$ is the normalized value of the $j$-th indicator in the $i$-th object,

$x_{i j}$ is the value of the $j$-th indicator in the $i$-th object,

$\bar{x}_{j}$ is the arithmetic mean of the $j$-th indicator,

$s_{j}$ is the standard deviation of the $j$-th indicator.

In the case of a minimization indicator (the desirable value is the lowest value of the indicator), the standard variable is defined as:

$$
z_{i j}=\frac{\bar{x}_{j}-x_{i j}}{s_{j}}
$$

In the next step it is necessary to express the final characteristic - the integral indicator, which we calculate for $i$-object as the weighted arithmetic mean of the normalized values:

where: $d_{i}$ is an integral indicator,

$$
d_{i}=\frac{1}{k} \sum_{j=1}^{k} z_{i j} v_{j}
$$

$v_{j}$ is the weight of the $j$-th indicator.

In the last step, it is necessary to determine the order of objects based on the integral indicator. The higher the value of the integral indicator is, the better the order of the object.

While the original indicator $x$ could have values from the interval $(-\infty,+\infty)$, the standard indicator may have any values, but in the case of normal distribution, values from -1 to +1 have $68 \%$ of the file's objects, $95 \%$ from -2 to +2 and $99.9 \%$ from -3 to +3 . In the case of another normal distribution, the percentages may change, according to the Chebyshev inequality, however, at least $89 \%$ of the objects have values from the interval -3 to +3 (more in Stankovičová and Vojtková, 2007).

Advantages of the method of standard variable:

- the method of standard variable takes into account the different variability of the individual indicators,

- that the object has a good position, it must have good results in all the analyzed indicators, it is not enough to achieve an excellent result with one or fewer indicators.

Disadvantages of the method of standard variable:

- results of this method are less sensitive to the extreme values of the indicators in the file,

- does not allow you to compare objects with share.

\section{Results and Discussion}

Input indicators do not have the same weights, so we need to use weighted data in the calculations (Table 1):

- Weights I - weights calculated using the coefficient of variation,

\begin{tabular}{|c|c|c|}
\hline Indicator & Weights I & Weights II \\
\hline Gross domestic product per capita & 0.2080 & 0.2154 \\
\hline Government gross debt as a percentage of GDP & 0.1691 & 0.0565 \\
\hline Inflation rate & 0.2138 & 0.1761 \\
\hline Unemployment rate & 0.1594 & 0.1473 \\
\hline Total fertility rate & 0.0341 & 0.2831 \\
\hline Infant mortality rate & 0.1170 & 0.0106 \\
\hline Crude divorce rate & 0.0986 & 0.1110 \\
\hline Total & 1.0000 & 1.0000 \\
\hline
\end{tabular}

- Weights II - weights calculated on the basis of correlation matrix.

Table 1: Weights calculating 
In the order of countries without using weights (Figure 1), Luxembourg is on the first place, followed by Ireland, Sweden and Finland. On the last places are Spain, Portugal and Greece. The Slovak Republic is on the $24^{\text {th }}$ place. Compared to the V4 countries (Slovakia, Czech Republic, Hungary, Poland), the Czech Republic is on the $12^{\text {th }}$ place, Poland, on the $15^{\text {th }}$ place, Hungary on the $25^{\text {th }}$ place.

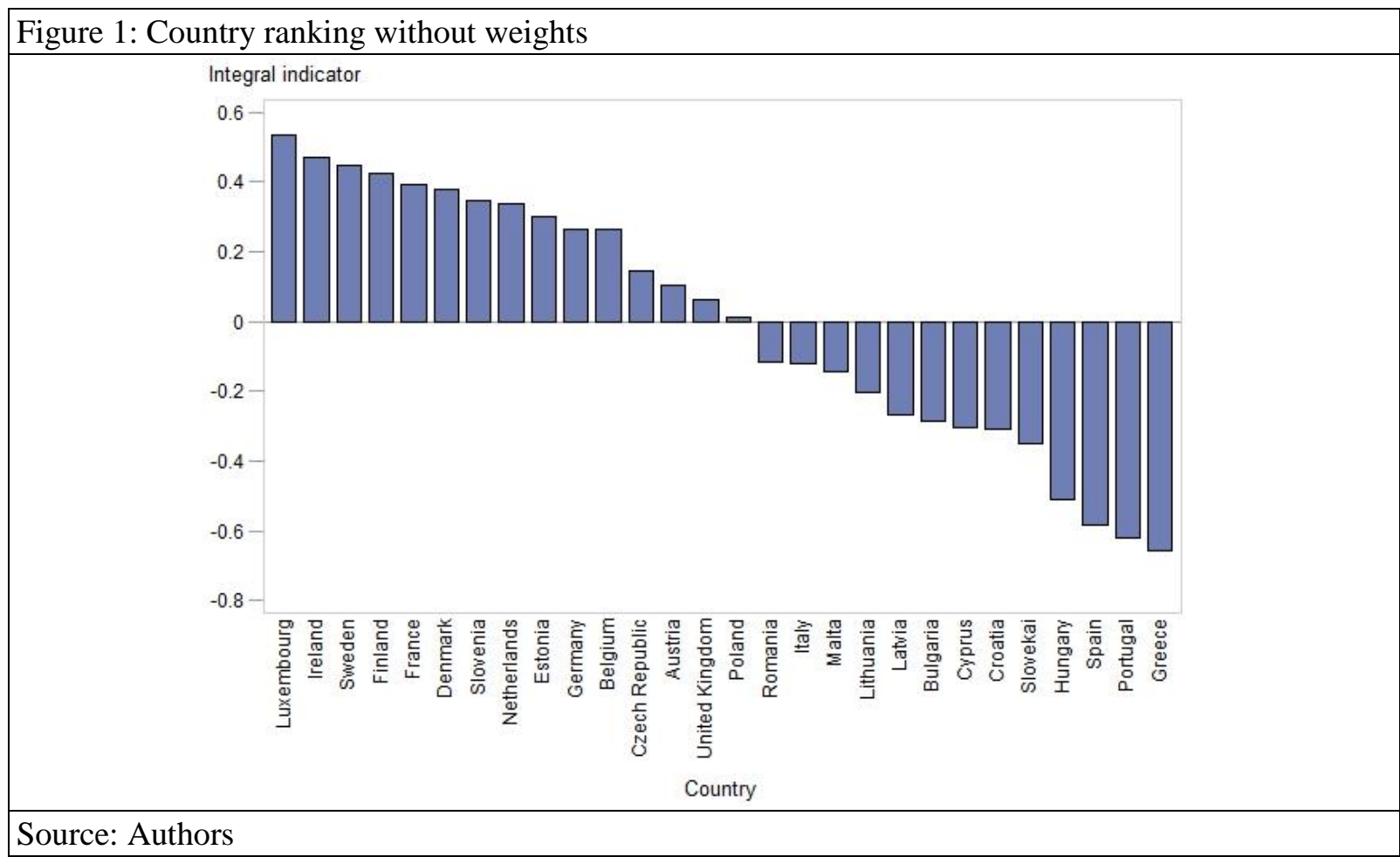

By using weights I (Figure 2) Luxembourg is on the first place (as well as in the calculation without weights), then Finland, Denmark and the Netherlands. The last places were occupied by countries such as Portugal, Greece and Hungary. The Slovak Republic is on the $23^{\text {rd }}$ place. In the V4 countries, Poland was best placed - on $12^{\text {th }}$ place, then the Czech Republic on the $14^{\text {th }}$ place, Slovakia as we have already mentioned on $23^{\text {rd }}$ place and last not only within the V4 countries but also within all the European Union countries is Hungary.

Figure 2: Country ranking with weights I

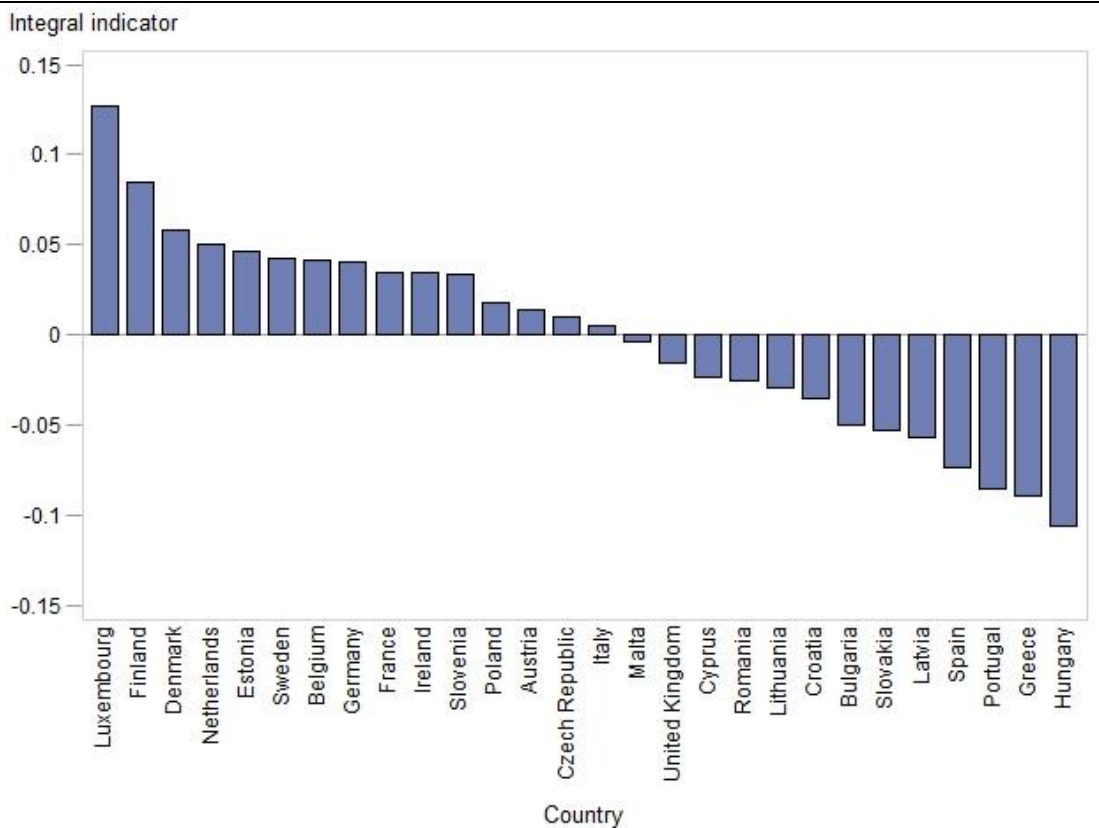

Source: Authors 
The results by using weights II (Figure 3) did not result in significant change compared to the previous results. On the first places are France, Ireland and Denmark. In the last places are Hungary, Portugal and Spain. The Slovak Republic is on the $22^{\text {nd }}$ place. The ranking of the V4 countries is as follows the Czech Republic is on the $15^{\text {th }}$ place, Poland on the $18^{\text {th }}$ and Hungary on $26^{\text {th }}$.

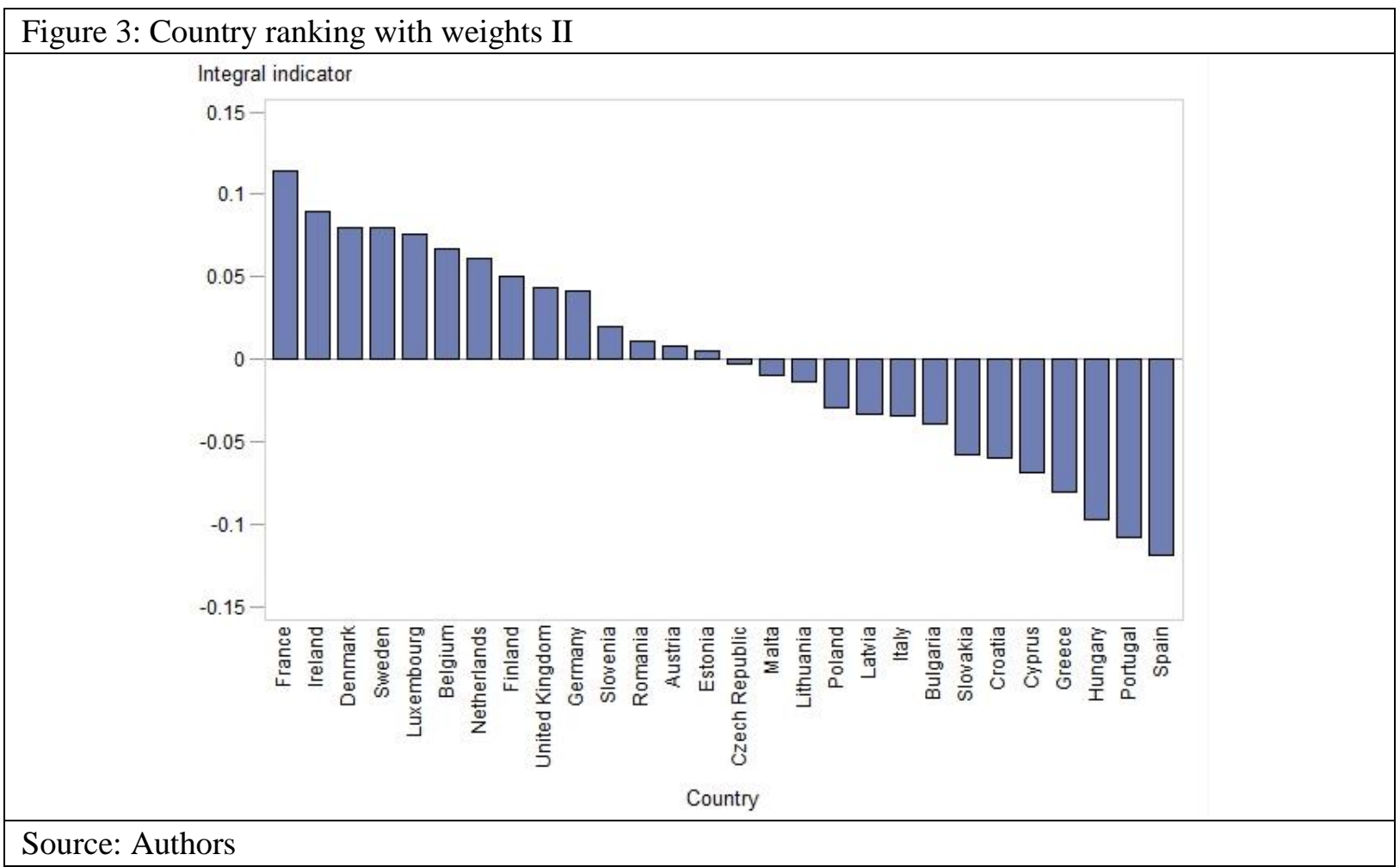

If we evaluate only the V4 countries themselves, on the third place with all types of weights is Slovakia, on the last place is Hungary and on the first two positions alternate the Czech Republic and Poland.

\section{Conclusion}

The aim of the paper was to analyze the European Union countries on the basis of selected socioeconomic and demographic indicators: gross domestic product per capita, government debt as a percentage of gross domestic product, inflation rate, unemployment rate, total fertility rate, infant mortality rate and crude divorce rate. In the analysis, we used one of the multidimensional comparison methods - the method of standard variable.

We realized the analysis on the basis of data from the year 2016, because more actual data was not yet available. Data we used was from the Eurostat website. The choice of the indicators themselves is very subjective. It is up to the analyst to select and include the indicators in the analysis.

In the first places using the method of standard variable are countries such as Luxembourg, Denmark, Finland, the Netherlands, Sweden, Ireland and France. One of the factors that could influence the ranking of countries may be their position because these countries are relatively close to each other. Finland was the first country in the world to give women the right to vote. The Netherlands and Luxembourg belong among the founding members of the European Union. The Netherlands has a rich supply of natural gas and is proud of its position as the largest exporter of beer in Europe. Luxembourg also stood at the birth of the United Nations and NATO. Denmark is considered the second oldest monarchy in the world and the oldest in Europe. Several surveys include Sweden's economy as the one with the most quality, and it is similar for its measure of competitiveness, quality of life, but also investment in research and education.

On the other hand, among the worst countries according to the analysis, we include Greece, Hungary, Spain and Portugal. Spain has huge unemployment problems. Up to 52\% of young people in Spain are unemployed. Unemployment in Spain has several reasons, one of which is labor market preregulation. Its regulations were designed to protect workers, but in fact only protect the unemployed 
from gaining jobs. Another reason for this is the long-term low growth of the Spanish economy. Portugal as well as Spain have major problems with unemployment. Unemployment of young people was $40 \%$ in 2013.

Poland and the Czech Republic were on the first and second place in comparison within the V4 countries. Slovakia ranked third in the application of three types of weights and Hungary ranked last.

By comparing the data using the added weights, we have reached approximately the same results.

In addition to the selected socio-economic and demographic indicators, the ranking of countries could influence other factors such as the geographical location of countries as well as the year of accession to the European Union.

\section{Acknowledgments}

This paper was supported by the Grant Agency of Slovak Republic - VEGA grant No. 1/0248/17 "Analysis of Regional Disparities in the EU based on Spatial Econometric Approaches".

\section{References}

Dufek, J. \& Minařík, B. (1984). Poznámka ke stanovení vah ukazatelu [Note on weights determination of indicators]. Statistika, 11, 486-489.

Hair, J. F., Black, W. C., Babin, B. J. \& Anderson, R. E. (2010). Multivariate data analysis. New York: Macmillan Publishing Company.

Gola, P. (2009, April 27) Veřejné dluhy ve světě - Česko si zatím stojí dobře [Public debts in the world - The Czech Republic is doing well]. Retrieved February 28, 2019 from http://www.finance.cz/zpravy/finance/217869-verejne-dluhy-ve-svetecesko-si-zatim-stoji-dobre

Gross domestic produkt at market prices. (2019, March 4). Retrieved from

https://ec.europa.eu/eurostat/tgm/table.do?tab=table\&init=1\&language=en\&pcode=tec $00001 \&$ plugin=1

Jílek, J. (1996). Metody mezinárodniho srovnávani [Methods of international comparison]. Praha: Vysoká škola ekonomická.

Jurčová, D. (2002) Krátky slovnik základných demografický pojmov [Short dictionary of basic demographic terms]. Bratislava: Výskumné demografické centrum.

Křovák, J. \& Študlar, J. (1983). Metody stanovení vah ukazatelu [Methods of weights determination of indicators]. Statistika. 12, 543-550.

Megyesiová, S. (2010). Hodnotenie krajín Európskej únie [Evaluation of European Union countries]. Národná a regionálna ekonomika VIII. Zborník príspevkov z medzinárodnej konferencie [National and Regional Economics VIII. Proceedings from international conference], 625-635.

Merriages and divorces (2019, March 4). Retrieved from https://ec.europa.eu/eurostat/cache/metadata/EN/demo_nup_esms.htm

Mortality (2019, March 4). Retrieved from https://ec.europa.eu/eurostat/cache/metadata/en/demo_mor_esms.htm

Pažitná, M. \& Labudová, V. (2007). Metódy štatistického porovnávania [Methods of statistical comparison]. Bratislava: Vydavatel'stvo EKONÓM.

Šenkýřová, L. (2010, September 20) Čo znamená často skloňovaný pojem inflácia? [What does the often inflected term inflation mean?] Retrieved February 28, 2019 from http://www.finance.sk/spravy/finance/35273-co-znamena-castosklonovany-pojem-inflacia/

Sharma, S. (1996). Applied Multivariate Techniques. New York: John Wiley \& Sons.

Stankovičová, I. (2007). Viackriteriálne hodnotenie zamestnanosti členských krajín EÚ na základe vybraných ukazovatel’ov Lisabonskej stratégie. [Multi-criteria evaluation of employment of EU member states based on selected indicators of the Lisbon Strategy] Retrieved March 19, 2019 from http://www.statspol.cz/oldstat/stakan/stakan-v2007/stakan2007.pdf\#page $=162$

Unemployment (2019, March 4). Retrieved from https://ec.europa.eu/eurostat/cache/metadata/en/une_esms.htm Vojtková, M. (2009). A Multidimensional Evaluation of Social Cohesion in the European Community. Studia i Prace Uniwersytetu Ekonomicznego w Krakowie, (6), 179-190.

Vojtková, M. \& Stankovičová, I. (2007). Viacrozmerné štatistické metódy s aplikáciami [Multidimensional statistical methods with applications]. Bratislava: Iura Edition. 